\title{
Reproductive potentials of rabbit does fed diets containing processed cassava peel/blood meal mixtures
}

\author{
Ojebiyi O. O. ${ }^{1 \star}$, Farinu G. O. ${ }^{1}$, Babatunde G. M. ${ }^{1}$, Togun V. A. ${ }^{2}$, Oseni S. O. ${ }^{3}$, Shittu M. D. ${ }^{2}$ and \\ Amao O. A. ${ }^{1}$ \\ ${ }^{1}$ Deparment of Animal Nutrition and Biotechnology, Ladoke Akintola University of Technology, \\ P.M.B. 4000, Oyo State, Nigeria. \\ ${ }^{2}$ Department of Animal Production and Health, Ladoke Akintola University of Technology, \\ P. M. B. 4000, Oyo State, Nigeria. \\ ${ }^{3}$ Department of Animal Science, Obafemi Awolowo University, lle Ife, Osun State, Nigeria.
}

Accepted 8 January, 2013

\begin{abstract}
A study was conducted for 12 weeks using sixty crossbred (Newzealand white $x$ Chinchilla) female rabbits to investigate the effect of feeding cassava peel/blood meal (CPBM) mixture (3:2) on their performance. Ten experimental diets were formulated with diets 1 serving as control. Diets 2, 3 and 4 had 10, 20 and 30\% inclusion of ash treated CPBM mixture (ATD+BM); diets 5, 6 and 7 had 10, 20 and $30 \%$ parboiled CPBM mixture (PAB+BM) while diets 8, 9 and 10 consist of sun dried CPBM mixture (SUD+BM) at 10, 20 and $30 \%$ inclusion level, respectively. The rabbits were divided into 10 treatments group of six rabbits each with each rabbit serving as a replicate in a Randomized Complete Block Design in a factorial arrangement. Age and attainment of puberty shows that SUD+BM had the highest number of does attaining puberty at 4 and 6 weeks, ATD+BM had the highest number at 8 weeks while PAB+BM had the highest number at 10 and 12 weeks. The effect of levels of inclusion of CPBM shows that the $10 \%$ levels of inclusion had the highest number of does attaining puberty at the 6th week and 8th week while $20 \%$ had highest number of rabbits attaining puberty at 4th and 10th week while at the 12th week rabbits on $20 \%$ had the highest number. It can be concluded that rabbits on PAB+BM performed better than others and $20 \%$ inclusion level was optimum for the attainment of puberty.
\end{abstract}

Key words: Reproductive potential, rabbit does, cassava peel, blood meal.

\section{INTRODUCTION}

Profitability in the rearing of rabbits like any other livestock in Nigeria as in other developing countries is influenced by a combination of resource inputs which are required to maintain a relatively high growth rate and reproductive performance as well as reducing the feeding cost which constitutes the highest operational cost. High production cost resulting from feeds is a major factor affecting the development of livestock industries in developing countries (Kawe et al., 2007). Thus, exploring the nutritional potentials of cheaper agro and agroindustrial by-products as feedstuffs for livestock continue to be the focus of animal producers

According to FAO, IFIF (2010), animal feeds play a leading role in the global food industry. This is because 
good and cheap animal feeds make livestock production more economically viable throughout the world. The potentials of some agricultural and industrial waste materials that can be moderately processed and incorporated in livestock feeds could therefore be exploited. Availability all the year round according to Ojebiyi et al. (2010) is one major factor determining the suitability of any non-conventional feedstuff (NCF) to avoid scarcity that may eventually hike the price. Two NCF are cassava peels and blood meal. Blood meal is an abattoir waste and is generated as long as slaughtering is done in abattoir daily while cassava peels is also available all year round. Blood contain a high protein rich in amino acid like lysine, but deficient in isoleucine. According to Fasuyi (2007), proteins from plant sources are perhaps the most naturally abundant and cheapest potential sources of protein but the build up of amino acids in plant and its by-products are also accompanied with other anti nutritive factors that render them less nutritious (Aletor and Adeogun, 1995). To be useful therefore (especially in monogastric diets) some forms of treatment methods need to be applied on cassava peels to reduce or eliminate the problems of Hydrocyanic Acid (HCN) thereby improving its utilization. Processing methods that have been used to enhance the feeding value of cassava include sun-drying (Akinfala et al., 2007), parboiling (Salami, 1999), soaking in water and retting (Salami and Odunsi, 2003); other method include provision of supplementary methionine in diets containing casaava peels and leaves (Ty Chhay et al., 2009).

Generally, the rate of reproduction in livestock is important but age at first mating is a more important factor because, if the unproductive period before the first litter can be shortened, rabbit productivity will naturally be increased (Labas et al., 1997). Puberty generally is considered as the time when spematogenesis starts in males and is defined as the age at first oestrus with ovulation in female (Bearden and Fuguay, 1980).

Feeding appears to be a major contributory factor in the attainment of puberty and sexual development because when feed is balanced, females can be serviced earlier than the usual 80 or $85 \%$ attainment of mature weight. Does generally reach puberty when they have grown up to between 70 and $75 \%$ of their mature weight and sexual behaviour (acceptance of mating) appears long before the ability to ovulate and bear litter (Labas et al., 1997). Nutrition therefore plays an important role in the attainment of sexual maturity by the female. It therefore becomes essential that when using some agricultural byproducts, special attention should be given to the potentially negative effects that the ingredient might have on the attainment of reproductive efficiency of the females.

The present study is aimed at evaluating the effect of feeding differently processed cassava peels/blood meal mixture (3:2), on growth, age at puberty and the development of reproductive organs of growing crossbred female rabbits.

\section{MATERIALS AND METHODS}

\section{Location}

The study was carried out at the Rabbitry Unit of the Teaching and Research Farm, Ladoke Akintola University of Technology Ogbomoso, Oyo State, Nigeria. Ogbomoso is in the derived Savannah zone of Nigeria. It is located approximately at the intersection of latitude 80151 North of the Equator and longitude 40 151 East of the Greenwich Meridian. It lies between 300 and 600 above sea level. The annual temperature ranges between 25.5 and $40^{\circ} \mathrm{C}$. The mean annual rainfall is $1247 \mathrm{~mm}$. The relative humidity is high in the early mornings (89\%) with marked decrease in the afternoon (62\%) throughout the year (Oguntoyinbo, 1978).

\section{Collection and preparation of test ingredients}

The test ingredients used were cassava peels and blood meal. Their collection and preparation was as described by Ojebiyi et al. (2010).

\section{Formulation of experimental diets}

The cassava peels differently processed and blood, meal were combined in the ratio $3: 2$ and mixed with other feed ingredients to formulate the (10) experimental diets (Table 1). Diet 1 Control $(0 \%$ cassava + blood meal), Diets 2, 5 and 8: $10 \%$ cassava peel + blood mixture, Diets 3, 6 and 9: 20\% cassava + blood mixture, Diets 4, 7 and 10: $30 \%$ cassava + blood mixture. For diets 2, 3 and 4 cassava peels were ash treated, for diets 5,6 and 7 they were parboiled and for diets 8, 9 and 10 they were sun dried. The cassava peel + blood mixture was introduced into diets in replacement of ground nut cake and palm kernel cake.

\section{Experimental animals and management}

A total of sixty female weaner rabbits (Newzealand white $x$ Chinchilla) whose ages were between 5 and 8 weeks were used for the experiment. The rabbits were allowed two weeks adjustment period during which they were fed with the control diets. Rabbits were weight- balanced at the end of adjustment period and divided into ten treatments groups of 6 does each with each doe serving as a replicate in a complete randomized block design RCBD in a factorial arrangement. The rabbits were housed individually in wood-wire cages designed in such a way that allows easy collection of faeces, urine and orts to avoid build up of odour and pathogenic diseases.

\section{Data collection}

The rabbits were weighed at the commencement of the experiment thereafter they were weighed weekly to determine weight gain. Record of actual feed intake and weight changes were kept for analysis. The experiment lasted for 12 weeks.

\section{Testing for puberty}

Testing for attainment of puberty commenced at the fourth week of the experiment and further assessment was done at 6, 810 , and 12 weeks post commencement of the experiment. The does were taken individually to a mature buck, the time of doe introduction to the buck (time in) was noted as well as the time of removal (time out). This was done to determine the receptivity or otherwise of the 
Table 1. Percentage composition of experimental diets.

\begin{tabular}{|c|c|c|c|c|}
\hline Ingredients (\%) & Control & $2-5-8$ & 3- 6- 9 & 4- 7- 10 \\
\hline Maize & 12.25 & 12.25 & 12.25 & 12.25 \\
\hline Corn bran & 40.00 & 40.00 & 40.00 & 40.00 \\
\hline Groundnut cake & 14.50 & 8.00 & 3.00 & 0.00 \\
\hline Palm kernel cake & 27.00 & 23.50 & 18.50 & 11.50 \\
\hline Cassava peels+blood meal mixture & 0.00 & 10.00 & 20.00 & 30.00 \\
\hline Fish meal & 0.50 & 0.50 & 0.50 & 0.50 \\
\hline Molasses & 2.50 & 2.50 & 2.50 & 2.50 \\
\hline Salt & 0.50 & 0.50 & 0.50 & 0.50 \\
\hline Bone meal & 2.50 & 2.50 & 2.50 & 2.50 \\
\hline *Vitamin premix & 0.25 & 0.25 & 0.25 & 0.25 \\
\hline Total & 100.00 & 100.00 & 100.00 & 100.00 \\
\hline
\end{tabular}

* Premix composition per kg diet: Vitamin A, 3,200,000 iu; Vitamin D3, 1,200 iu; Vitamin E, 3,200 iu; Vitamin $\mathrm{K}_{3}$, $800 \mathrm{mg}$; Vitamin $\mathrm{B}_{1}, 400 \mathrm{mcg}$; Selenium (Se), $40 \mathrm{mg}$; Manganese (Mn), 32,000 mg; Pantothenic acid, $2000 \mathrm{mg}$; folic acid, $200 \mathrm{mg}$; Chlorine chloride, 60000 mg; Iron (Fe), 8,000 mg; (Cu), 3,200 mg; Zinc (Zn), 200 mg; Cobalt (Co), 90 mg; lodine (I), 800 mg.

doe to the buck, the durations were recorded as doe's indifference, doe aggression and or doe tolerance. Display of lordosis (a characteristic pose, with the back arched downwards and hindquarters raised (Labas et al., 1997) was used as a sign of attainment of sexual receptivity and hence maturity.

\section{Measurement of reproductive organs}

At the end of the experiment at 12 weeks four rabbits from each treatment were randomly selected, slaughtered opened up and the reproductive organs carefully removed. Cervix width, vagina width, left uterus width, right uterus width, left ampulla width, right ampulla width reproductive tract length, vagina length, left uterus length, right uterus length, left ampulla length and right ampulla length were measured using a sensitive weighing balance and meter rule.

\section{Laboratory analysis}

The proximate analysis of the experimental diets was done using the method of AOAC (1990) while HCN determination was done using the procedure described by Egan et al. (1998) and Bradbury et al. (1999).

\section{Data analysis}

All data collected were subjected to analysis of variance using the general linear model (GLM) SAS (2000) and significant differences were compared using Duncan's New Multiple Range Test of the same package.

\section{RESULTS}

The chemical composition of the experimental diets as presented in Table 2 shows that the diets are similar in composition. The HCN content as determined by Spectrophotometric method $(\mathrm{mg} / \mathrm{kg})$ ranged from 0.00 for the control, $7.69,8.84,12.34 \%$ for 10.20 and $30 \%$ ATD +BM respectively. $1.94,3.75,4.82 \%$ for 10.20 , and $30 \%$ $\mathrm{PAB}+\mathrm{BM}$ and $11.76,13.87$ and $15.37 \%$ respectively for
10.20 and $30 \%$ SUD +BM.

The effect of treatment methods on the number of does attaining sexual receptivity is presented in Figure 1. Appraisal at 4 weeks post-commencement of experiment shows that Rabbit does fed with diets containing SUD+BM and $\mathrm{PAB}+\mathrm{BM}$ had higher $(\mathrm{P}<0.05)$ number of rabbits, attaining puberty than those fed with the control and ATD+BM diets. At six weeks post commencement of experiment rabbits on SUD+BM diet and those on ATD+BM had the highest $(P<0.05)$ number of does attaining puberty closely followed by does fed the control diet. The rabbits fed $\mathrm{PAB}+\mathrm{BM}$ diet recorded the least number of does attaining puberty.

Appraisal at 8 weeks shows that the rabbits on ATD+BM and SUD+BM diets had the highest $(P<0.05)$ number of does attaining puberty followed by the does fed $\mathrm{PAB}+\mathrm{BM}$ diet .The rabbits on the control diet had the least $(P<0.05)$ number of rabbits attaining puberty. The doe's appraisal at the 10th week of the experiment reveals that rabbits on the $\mathrm{PAB}+\mathrm{BM}$ had the highest $(P<0.05)$ number of does attaining puberty followed by the rabbits on $A T D+B M$ and then the rabbits on the control diet. The does on SUD+BM diet recorded the least number of rabbits. The appraisal at the twelve week shows that rabbits fed diets containing $P A B+B M$ recorded the highest $(P<0.05)$ number of rabbits attaining puberty closely followed by does on ATD+BM and SUD+BM diets. The control recorded the least number of does at the 12th week.

The effect of levels of inclusion of cassava peel/blood meal mixture on attainment of puberty is presented in Figure 2. At 4 weeks post-commencement of the experiment does on $20 \%$ inclusion levels of cassava peel/blood meal mixture had high $(\mathrm{P}<0.05)$ number of rabbits attaining puberty than other inclusion levels. At the 6th week, does on $10 \%$ inclusion levels recorded the greater $(P<0.05)$ number of does attaining puberty while others had similar number of does reaching puberty. The 
Table 2. Chemical composition of the experimental diets.

\begin{tabular}{lcccccccccc}
\hline \multirow{2}{*}{ Parameter } & $\mathbf{8}$ & $\mathbf{1 0}$ Diets \\
\cline { 2 - 12 } & $\mathbf{1}$ & $\mathbf{2}$ & $\mathbf{3}$ & $\mathbf{4}$ & $\mathbf{5}$ & $\mathbf{6}$ & $\mathbf{7}$ & $\mathbf{8}$ & $\mathbf{9}$ & $\mathbf{1 0}$ \\
\hline Dry matter & 89.1 & 89.6 & 89.0 & 89.0 & 89.5 & 89.1 & 89.2 & 89.4 & 89.3 & 89.4 \\
Crude protein & 18.3 & 16.7 & 16.9 & 18.2 & 17.9 & 17.9 & 18.0 & 17.1 & 17.7 & 17.5 \\
Crude fibre & 8.87 & 7.87 & 8.14 & 8.04 & 8.09 & 7.98 & 7.08 & 8.94 & 6.70 & 8.15 \\
Ash & 7.32 & 6.82 & 6.94 & 7.13 & 7.18 & 7.24 & 6.95 & 6.99 & 6.94 & 6.86 \\
Ether extract & 4.13 & 3.69 & 3.73 & 3.78 & 3.89 & 4.04 & 3.95 & 3.86 & 3.93 & 4.07 \\
Cyanide $(\mathrm{mg} / \mathrm{kg})$ & 0.00 & 7.69 & 8.84 & 12.34 & 1.94 & 3.75 & 4.82 & 11.76 & 13.87 & 15.37 \\
\hline
\end{tabular}

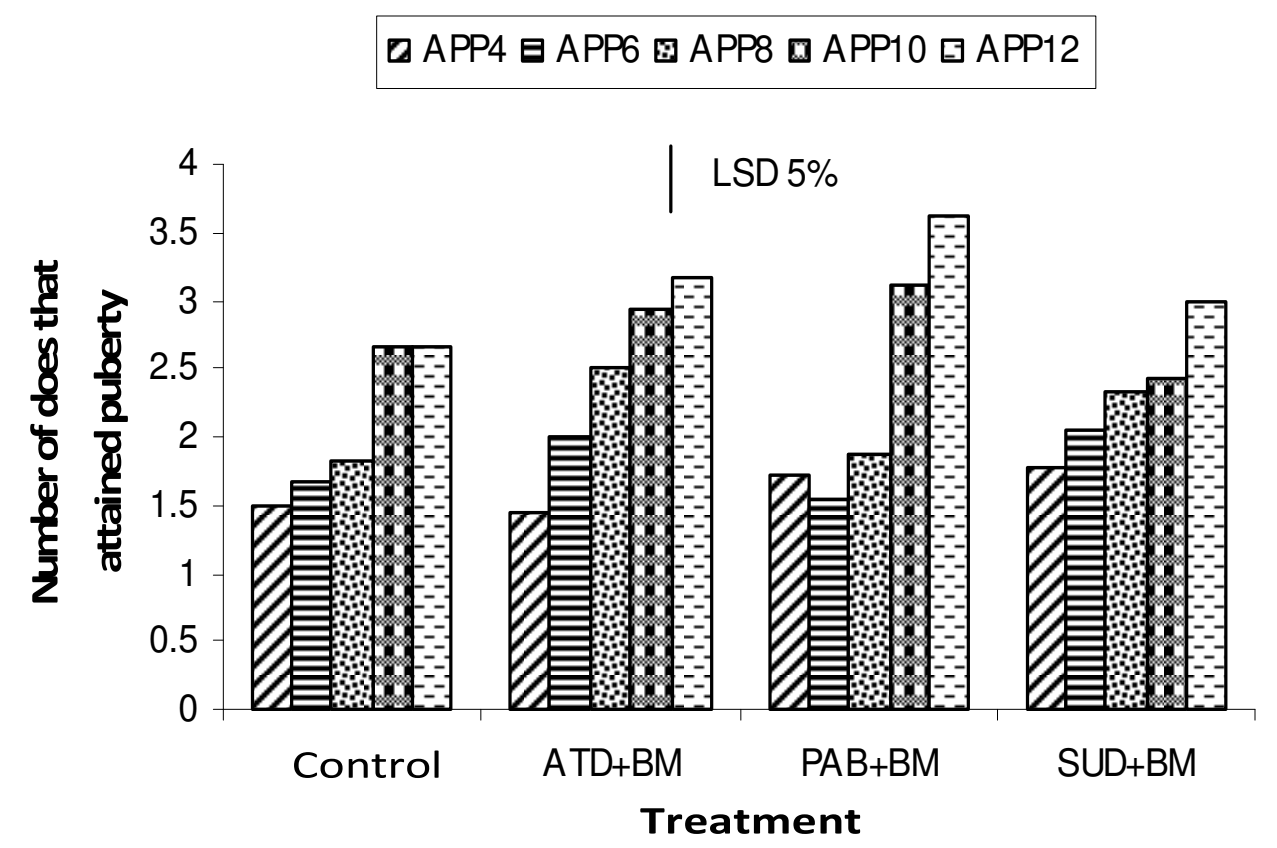

Figure 1. Effect of treatment methods on the number of does attaining sexual receptivity.

observations at the 8th week follow similar trend with the 6 th week appraisal. The $20 \%$ inclusion levels had the highest number of does attaining puberty at 10 weeks while the $30 \%$ inclusion level had the least $(p<0.05)$. Appraisal at 12 weeks shows that Rabbit does fed 10 and $20 \%$ cassava feel/blood meal mixture recorded the highest $(P<0.05)$ number of does attaining puberty. The control and $30 \%$ had similar number of does. The age and weights at puberty are presented in Table 3 .

At the early stages of appraisal between the $4^{\text {th }}$ and $6^{\text {th }}$ week post-commencement of experiment, the ATD+BM and SUD+BM diets had higher number of rabbits attaining puberty. However at the latter stage of the appraisal (between 10 to 12 weeks), the PAB+BM recorded the highest number of rabbits attaining puberty.

\section{DISCUSSION}

The crude protein of the diets used in this study falls within the ranged used by Ojebiyi et al. (2006), Amafule and Ironkwe (2007), but lower than that reported by Ani (2007). The crude protein values fall within the range recommended by NRC (1984).

The higher number of rabbits attaining puberty in $\mathrm{PAB}+\mathrm{BM}$ diet at $10^{\text {th }}$ and $12^{\text {th }}$ weeks implied, that the residual cyanide in the diets may be responsible as the cumulative effect of the daily ingestion of cyanide began to manifest with advancement in age of the rabbits. The least cyanide containing diets were those having the $\mathrm{PAB}+\mathrm{BM}$. Puberty occurs as the mature weight is approached, growth is declining and when all parts of the reproductive tract becomes functional for the first time. Under-nutrition can delay puberty and age and weight at puberty can also be influenced by some obnoxious materials in ingredients used for ration formulation (Gbore et al., 2007). Such materials are mycotoxins with oestrogenic effects which have been reported to impede breeding (Pertizinger and Weindenbach, 2002). In this study, it does appear that the residual cyanide in the diets 


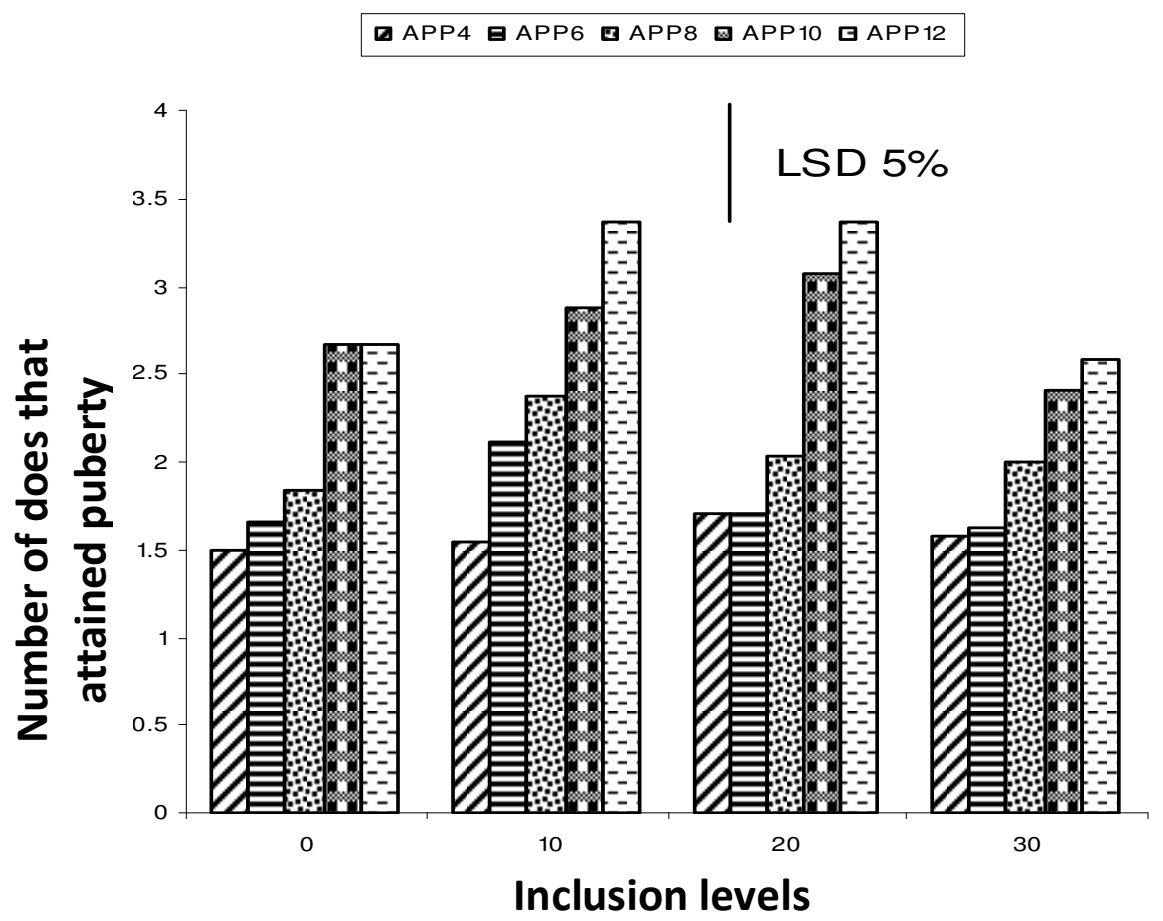

Figure 2. Effect of inclusion levels on the number of does attaining sexual receptivity.

was well tolerated and that the treatment methods used were effective in reducing cyanide to tolerable level. That these rabbits did not manifest any visible negative effect from the dietary cyanide may have been due to their nutritional status and nutritional adequacy of the diets since malnutrition has been claimed to enhance susceptibility of animals to mycotoxins and thus their reproductive efficiency (Panda et al., 1970).

The main effect of pre treatment methods and levels of inclusion of cassava peels/blood meal mixtures on the development of reproductive organs of rabbit does is presented in Table 4. Although pre treatment methods had no significant $(P>0.05)$ effect on the final weights as well as the cervix width, uterus lengths and tract length of the does it had effects $(P<0.05)$ on all other parameters measured. The vaginal widths $(0.73 \mathrm{~cm})$ for the rabbits on the control diet is significantly $(P<0.05)$ higher than those of the ash treated, parboiled and sun dried treatments. The effect on left uterus width did not follow any particular trend, the right uterus width however for rabbits on the sun dried cassava/blood meal mixtures is significantly $(P<0.05)$ higher than other treatments that are similar $(p>0.05)$. The effects of pre treatment methods on the left and right ampullae's width followed a similar trend. The values for rabbits on ATD+BM and $P A B+B M$ diets are higher $(p<0.05)$ than the values for the rabbits on the control and SUD+BM diets that were similar. On the other hand, values of the left and right ampullae lengths are higher $(p<0.05)$ for rabbits on the control diets than other treatments groups that were similar.

The main effect of inclusion levels of cassava peels/blood meal mixtures on the development of reproductive organs of rabbit does also shows that the final weights of the rabbits were not significantly $(P>0.05)$ affected by the levels of inclusion. However, the levels of inclusion significantly $(p<0.05)$ affected all other parameters except the right ampulla width. The effect of inclusion levels on parameters like cervix width, vaginal width, right and left uterus width, left ampulla length and right ampulla length showed that at higher levels of inclusion lower values were obtained thus implying a depressing effect. Rabbits fed with $30 \%$ inclusion level of cassava peel / blood meal mixtures had the lowest $(p<0.05)$ cervix width while the vaginal width values for 20 and $30 \%$ inclusion though similar, were significantly $(p<0.05)$ lower than the values for rabbits fed the control and $10 \%$ diets. Reproductive tract length values of rabbits on 20 and $30 \%$ inclusion are significantly $(P<0.05)$ lower than the values for the control and $10 \%$ inclusion.

Vaginal length for rabbits on control, 10 and $20 \%$ are higher $(P<0.05)$ than $30 \%$ inclusion level. Right and left ampulla length of rabbit 10, 20 and $30 \%$ were affected by the level of inclusion of cassava peel/blood meal as they were lower $(\mathrm{P}<0.05)$ than control meaning that the various inclusion levels had adverse effect on the left ampulla length.

Small vaginal width would lead to reproductive failure as intromission of the penis would be affected and difficult parturition may occur. Conversely wider vaginal 
Table 3. Age and weight at puberty as influenced by dietary treatments.

\begin{tabular}{|c|c|c|c|c|c|c|c|c|c|c|c|}
\hline \multirow{2}{*}{ Parameter } & \multicolumn{10}{|c|}{ Diets } & \multirow{2}{*}{ SEM } \\
\hline & 1 & 2 & 3 & 4 & 5 & 6 & 7 & 8 & 9 & 10 & \\
\hline Age at puberty (weeks) & $18.50^{\mathrm{bc}}$ & $18.32^{b}$ & $19.20^{\mathrm{a}}$ & $20.00^{\mathrm{a}}$ & $18.00^{c}$ & $20.50^{a}$ & $19.00^{\mathrm{a}}$ & $18.67^{b}$ & $17.50^{c}$ & $18.00^{\mathrm{C}}$ & 0.56 \\
\hline Weight at puberty $(\mathrm{g})$ & $1335.50^{\mathrm{a}}$ & $1273.33^{b}$ & $1323.00^{\mathrm{a}}$ & $1344.00^{a}$ & $1292.33^{b}$ & $1282.25^{\mathrm{b}}$ & $1460.00^{\mathrm{a}}$ & $1187.65^{b}$ & $1273.00^{b}$ & $1227.50^{c}$ & 52.68 \\
\hline
\end{tabular}

${ }^{\mathrm{abc}}$ Mean with different superscript along the same row are significantly different $(\mathrm{P}<0.05)$.

Table 4. Main effect of pre-treatment methods and levels of inclusion of cassava peel/blood meal mixtures on final weight and development of reproductive organs of rabbit does.

\begin{tabular}{|c|c|c|c|c|c|c|c|c|c|}
\hline \multirow{2}{*}{ Parameter } & \multicolumn{4}{|c|}{ Pre-treatments methods } & \multicolumn{4}{|c|}{ Inclusion levels (\%) } & \multirow{2}{*}{ SEM } \\
\hline & CC & AA & PP & SS & CC & 10 & 20 & 30 & \\
\hline Initial weight (g) & 609.90 & 610.00 & 610.70 & 612.70 & 609.90 & 612.30 & 613.60 & 611.10 & 139.00 \\
\hline Final weight $(\mathrm{g})$ & 1336.30 & 1277.50 & 1314.40 & 1323.3 & 1363.30 & 1334.06 & 1312.31 & 1312.50 & 260.00 \\
\hline Cervix width (cm) & 0.83 & 0.80 & 0.85 & 0.90 & $0.83^{a}$ & $0.92^{\mathrm{a}}$ & $0.91^{a}$ & $0.78^{b}$ & 0.15 \\
\hline Vagina width (cm) & $0.73^{\mathrm{a}}$ & $0.61^{\mathrm{b}}$ & $0.62^{\mathrm{b}}$ & $0.67^{b}$ & $0.73^{a}$ & $0.76^{\mathrm{a}}$ & $0.64^{\mathrm{b}}$ & $0.58^{b}$ & 0.13 \\
\hline Left uterus width (cm) & $0.41^{\mathrm{a}}$ & $0.29^{b}$ & $0.35^{\mathrm{ab}}$ & $0.40^{\mathrm{a}}$ & $0.41^{\mathrm{a}}$ & $0.38^{b}$ & $0.36^{b}$ & $0.34^{b}$ & 0.07 \\
\hline Right uterus width (cm) & $0.39^{b}$ & $0.30^{\mathrm{b}}$ & $0.35^{\mathrm{b}}$ & $1.96^{\mathrm{a}}$ & $1.52^{\mathrm{a}}$ & $0.37^{\mathrm{b}}$ & $0.35^{\mathrm{b}}$ & $0.39^{b}$ & 0.14 \\
\hline Left ampulla width (cm) & $0.37^{\mathrm{b}}$ & $0.46^{\mathrm{a}}$ & $0.46^{\mathrm{a}}$ & $0.35^{\mathrm{b}}$ & $0.43^{\mathrm{a}}$ & $0.41^{a}$ & $0.38^{b}$ & $0.37^{\mathrm{b}}$ & 0.08 \\
\hline Right Ampulla width (cm) & $0.31^{\mathrm{b}}$ & $0.45^{\mathrm{a}}$ & $0.47^{\mathrm{a}}$ & $0.31^{\mathrm{b}}$ & 0.39 & 0.39 & 0.39 & 0.37 & 0.08 \\
\hline Reproductive tract length (cm) & $17.12^{b}$ & $19.56^{\mathrm{a}}$ & $17.54^{\mathrm{ab}}$ & $18.19^{a}$ & $19.73^{\mathrm{a}}$ & $18.47^{\mathrm{ab}}$ & $17.12^{b}$ & $16.65^{\mathrm{b}}$ & 3.55 \\
\hline vigina length $(\mathrm{cm})$ & $5.52^{\mathrm{b}}$ & $6.44^{\mathrm{a}}$ & $5.09^{b}$ & $5.41^{\mathrm{b}}$ & $5.52^{\mathrm{ab}}$ & $5.72^{\mathrm{ab}}$ & $6.27^{\mathrm{a}}$ & $4.85^{\mathrm{b}}$ & 1.10 \\
\hline Left uterus length (cm) & 5.35 & 5.47 & 5.14 & 5.00 & 5.35 & 5.08 & 5.36 & 5.27 & 1.03 \\
\hline Right uterus length (cm) & 4.95 & 5.56 & 5.03 & 5.47 & $4.95^{\mathrm{b}}$ & $5.10^{\mathrm{b}}$ & $5.62^{\mathrm{a}}$ & $5.03^{b}$ & 1.03 \\
\hline left Ampulla length (cm) & $1.32^{\mathrm{a}}$ & $1.00^{\mathrm{b}}$ & $1.07^{\mathrm{b}}$ & $1.03^{b}$ & $1.32^{\mathrm{a}}$ & $1.00^{\mathrm{b}}$ & $1.05^{\mathrm{b}}$ & $1.12^{\mathrm{b}}$ & 0.22 \\
\hline Right Ampulla length (cm) & $1.27^{\mathrm{a}}$ & $1.00^{\mathrm{b}}$ & $1.06^{b}$ & $1.13^{\mathrm{ab}}$ & $1.27^{\mathrm{a}}$ & $1.12^{\mathrm{b}}$ & $1.10^{\mathrm{b}}$ & $1.12^{\mathrm{b}}$ & 0.22 \\
\hline
\end{tabular}

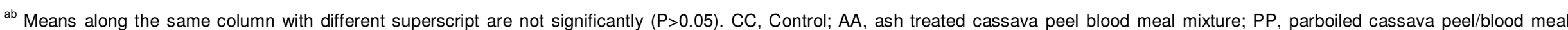
mixture; SS, sun dried cassava peels/blood meal mixture.

width aids copulation, prevent reproductive tract injuries during parturition (dystocia) and foetal suffocation during parturition (Bearden and Fuquay, 1980). Long vagina length according to Frandson (1981) aids intromission and successful parturition.

Shorter ampulla length will lead to poor conception while longer ampulla length delays the ovum for several hours during transportation so that fertilization can occur at the ampullary isthmic junction (Senger, 1999).

Wider cervix is advantageous in artificial insemination. Smaller uterus width according to Senger (1999) is known to result in foetal suffocation and death, dystocia, abortion and delivery of still birth, while a wide uterus width give more space for implantation and development of the fetus in the uterus thus resulting in successful gestation and foetal expulsion during parturition (Osinowo, 2006). Longer reproductive tract length according to Labas et al. (1997) is an indication of proper sexual development and thus aids all reproductive processes such as conception, gestation and parturition. 


\section{Conclusion}

The treatment methods of cassava peels as well as the inclusion levels of cassava peel/blood meal mixtures did not affect the final live weight of rabbits does, thus implying that the methods were effective in reducing the $\mathrm{HCN}$ to a tolerable level for growth.

The $20 \%$ inclusion level of cassava peel/blood meal mixture appears to be the optimum in this study. It can be inferred from the study that since the diets having the inclusion of the test ingredients compared favorably with the control, the ingredients have potential usefulness in rabbit production.

The developments of the reproductive organ were adversely affected implying that the residual $\mathrm{HCN}$ had negative effect on the reproductive organs.

Caution should therefore be exercised when feeding cassava peel-based diet to rabbit does intended for breeding purposes.

It should be noted however that although blood is one of the highest non-synthetic sources of nitrogen, there could be possible negative side effects of contamination and re-contamination after cooking or processing and during storage, transport and handling as well as disease transmission from infected source animal in adding blood to the mixture.

\section{REFERENCES}

Akinfala EO, Matanmi O, Fatufe AA (2007). Effect of residual cyanogenic glucosides in cassava based diets on serum metabolites of metabolites of cockerels chicks. Proceedings of the $32^{\text {nd }}$ Annual conference of the Nigerian Society for Animal Production (NSAP) March 18-21, University of Calabar, Nigeria. pp. 105-107.

Aletor VA, Adeogun A (1995). Nutrients and anti nutrients components of some tropical leafy vegetables. Food Chem. 54(4):375-379.

Amafule KU, Ironkwe MO (2007). Response of weaner rabbits fed graded levels of raw bambara groundnut (Vigna subterranean) (L) diets. Proc of $32^{\text {nd }}$ Ann. Conf of the Nig. Soc of Anim. Prod. March 2007, Univ. of Calabar, Nigeria. pp. 236-239.

Ani OA (2007). Nutrient intake digestibility and utilization by rabbits fed graded levels of raw bombaranut (Voandzeia subterranca L) waste. Proc of the $32^{\text {nd }}$ Ann. Conf. of the Nigeria Society for Animal production (NSAP) March 2007, University of Calabar, Nigeria. pp 282-287.

AOAC (Association of Official Analytical Chemist) (1990). Official methods of Analysis (15th edition), Washington D. C., USA.

Bearden J, Fuquay JW (1980). Apply Animal Reproduction $1^{\text {st }}$ edition 1980. Reston Publishing Company Inc. A Prentice Hall Company Reston, Virgines. p. 65.

Bradbury MG, Egan SV, Bradbury JH (1999). Determination of all forms of cyanogens in cassava roots and cassava products using picrate paper kits. J. Sci. Food Agric. 79:593-601.

Egan SV, Yeoh HH, Brabury JH (1998). The caynogenic potential of cassava. J. Sci. Food and Agric. 76:39-48.
FAO, IFIF (2010). Good practices for industry-Implementing the codex Alimentarius Code of Practice on Good Animal Feeding. FAO Animal Production and Health Manual. Rome. p. 9.

Fasuyi AO (2007). Biochemical and nutritional implication of Telfaira occidentalis (Ugwu) leaf meal as protein supplement in broiler starter diets. Proc. $32^{\text {nd }}$ Ann. Conf. Animal Sci. Ass. of Nigeria (ASAN). March 2007, University of Calabar, Nigeria. pp. 295-298.

Frandson RD (1981). Anatomy and Physiology of Farm Animal $1^{\text {st }}$ edition LEA and Febiger, Philadelphia.

Gbore FA, Ewuola EO, Ogunlade JT, Idahor KO, Solako AO Egbunike GN (2007). Spermatogenesis, gonadal sperm reserves and fertility of rabbits fed micro doses of fumonisin. Nig. J. Anim. Prod. 34(2):316322.

Kawe SM, Faruk IU, Richard AS (2007). Growth Response and carcass characteristics of rabbits fed graded levels of Leucaena leucocephala diets. In:Proc $32^{\text {nd }}$ Ann. Conf. of the Nig. Soc. for Anim. Prod. March 2007, University of Calabar, Nigeria. pp. 425-454.

Labas F, Coudert P, De-Rochambeau H, The bault RG (1997). The Rabbit. Husbandry, health and production. FAO Animal Production and health series Rome Italy 21:203.

NRC (1984). Nutrient requirements of Domestic Animals. Nutrient requirement of rabbits. $2^{\text {nd }}$ revised edition. National Academy of science, Washingon D.C.

Oguntoyinbo JS, Climate. In: Oguntoyinbo JS (1978). (eds). Geography of Nigeria Development, Heinemann Nigeria Ltd, Ibadan. p. 78.

Ojebiyi OO, Farinu GO, Babatunde GM (2010). Nutritional potentials of differently processed cassava peels and blood meal as livestock feed ingredients. J. Agric. Forestry Social Sci. 8(1):195-207.

Ojebiyi OO, Farinu GO, Babatunde GM, Morunfolu OO (2006). Effect of varying levels of sun dried cassava peel blood meal mixture (3:2) on growth performance and organ characteristics of weaner rabbits. J. Anim. Vet. Adv. 5(11):886-890.

Osinowo OA (2006). Introduction to Animal Production, $1^{\text {st }}$ Edition Sophie Academic Services. Abeokuta, Nigeria. pp. 21-30.

Panda PC, Sreenivasamurthy V, Parpia HAB (1970). Effect of afflatoxin $B$ on reproduction in rats. J. Food Sci. Technol. 7:20-22.

Pertizinger E, Weidenbach A (2002). Mycotoxins in the food chain: the role of ochratoxins. Livest. Prod. Sci. 76:245-250.

Salami RI (1999). The use of two empirical methods of substitution of feedstuffs: parboiled cassava peel meal versus maize in the diets of growing cockerels. Nig. J Anim. Prod. 26:78-83.

Salami RI, Odunsi AA (2003). Evaluation of processed cassava peel meal as substitutes for maize in the diets of layers. Int. J. Poult. Sci. 2(2): 112-116.

SAS (2000). Users statistics. Statistical Analyses system Institute Inc. Cary, NC, USA.

Senger PL (1999). Pathways to Pregnancy and Parturition. $1^{\text {st }}$ Revised ed. Current Conceptions Inc.Pullman Washington,USA, pp. 168-186.

Ty Chhay, Khieu B, Preston TR (2009). Effect of wilting cassava leaves and supplementing them with DL-methionine, on intake, growth and feed conversion in growing pigs. Lives. Res. Rural. Dev. 21(1): 1-7. 